\title{
Affecting NF-kB cell signaling pathway in chronic lymphocytic leukemia by dendrimers-based nanoparticles
}

\author{
Ida Franiak-Pietryga ${ }^{\mathrm{a}, \mathrm{b}, \mathrm{c}, \mathrm{d}, *}$, Kinga Ostrowskac ${ }^{\mathrm{c}}$, Henryk Maciejewski ${ }^{\mathrm{e}}$, Barbara Ziemba ${ }^{\mathrm{a}}$, \\ Dietmar Appelhans ${ }^{\mathrm{f}}$, Brigitte Voit ${ }^{\mathrm{f}}$, Magdalena Jander ${ }^{\mathrm{d}}$, Jacek Treliński ${ }^{\mathrm{g}}$, Maria Bryszewska ${ }^{\mathrm{h}}$, \\ Maciej Borowiec ${ }^{\mathrm{a}}$ \\ ${ }^{a}$ Department of Clinical and Laboratory Genetics, Medical University of Lodz, 251 Pomorska St., 92-213 Lodz, Poland \\ b Department of Ophthalmology, University of California San Diego, 9500 Gillman Dr, La Jolla, CA 92093-0718, United States \\ ${ }^{\mathrm{c}}$ Laboratory of Clinical and Transplant Immunology and Genetics, Copernicus Memorial Hospital, 62 Pabianicka St., 93-513 Lodz, Poland \\ ${ }^{\mathrm{d}}$ GeneaMed LTD, 16/18/904 Kopcinskiego St., 90-232 Lodz, Poland \\ e Department of Computer Engineering, Wroclaw University of Technology, 11/17 Janiszewskiego St., 50-372 Wroclaw, Poland \\ ${ }^{\mathrm{f}}$ Leibniz Institute of Polymer Research Dresden, Hohe Str. 6, D-01069 Dresden, Germany \\ ${ }^{g}$ Department of Hematology, Medical University of Lodz, Copernicus Memorial Hospital, 62 Pabianicka St., 93-513 Lodz, Poland \\ h Department of General Biophysics, Faculty of Biology and Environmental Protection, University of Lodz, 141/143 Pomorska St., 90-236 Lodz, Poland
}

\section{A R T I C L E I N F O}

\section{Keywords:}

Chronic lymphocytic leukemia (CLL)

Gene expression

Glycodendrimer, NF-кB

Signaling pathway

PPI dendrimer

\begin{abstract}
A B S T R A C T
The complex genetic diversity of chronic lymphocytic leukemia (CLL) makes it difficult to determine the effective and durable therapy beneficial to patients. During the several past years' significant insights in the biology of the disease and its treatment have been made, allowing for the identification of promising novel therapeutic agents. The investigation of signaling pathways to understand the biological character of CLL together with the development of molecular profiling is key in personalized approach in therapy for this disease. As it was already proven, maltotriose (M3) modified fourth generation poly(propylene imine) dendrimers (PPIG4) modulate BCR, TRAIL and WNT signaling pathway gene expression in CLL cells and strongly influence their survival by inducing apoptosis and inhibiting proliferation. The aim of this study was to evaluate the influence of PPI-G4-M3 dendrimers on NFKB pathway gene expression in CLL (MEC-1) cells with $60 \mathrm{~K}$ microarray, as it is one of the major factors in the pathogenesis of B-cell neoplasms. The findings were compared with those obtained with Fludarabine (FA) and the results indicate that PPI-G4-M3 dendrimers affect the expression of the examined genes and exert comparable effect on the CLL cells to FA. Dendrimers are one of the most potent groups of nanometer-sized macromolecules for closing the gap between the present ineffective treatment and the future effective personalized therapy due to their potential versatile biological properties.
\end{abstract}

\section{Introduction}

Despite the enhanced molecular understanding and the clinical diagnosis improvement, chronic lymphocytic leukemia (CLL) still remains a disease without a well-defined genetic alteration responsible for its onset (Doménech et al., 2012). As B-CLL cells are characterized by a low dividing rate, they are less susceptible to chemo- and radiation therapy commonly used in cancer treatment, which make CLL difficult to cure. Standard therapy for CLL includes a combination of chemotherapeutics such as fludarabine (FA), cyclophosphamide and rituximab (FCR) but it is not suitable for all the patients because of the drug resistance or the side effects of strong chemotherapy (Smolej, 2016; Tam et al., 2008). Although the past several years have brought huge and significant changes in therapeutic paradigms of CLL while novel drugs like ibrutinib or idelalisib have been approved (Byrd et al., 2015; Ramanathan et al., 2016), alternative therapeutics approaches are still necessary if longer survival rates and an ultimately cure in CLL patients are be achieved.

One of the proposed alternative therapeutic approaches in CLL treatment is a substitution of a standard chemotherapy by polymeric therapeutics, which possesses another molecular biological pathway for inducing apoptosis of CLL cells. For substituting anticancer drug fludarabine, open shell (OS) and dense shell (DS) maltotriose (M3)-modified fourth-generation poly(propylene imine) (PPI-G4) dendrimers (PPI-G4-OS-M3 or PPI-G4-DS-M3; Fig. 1) have been found and further validated as possible alternative drug for fludarabine(Franiak-Pietryga

\footnotetext{
* Corresponding author at: Department of Clinical and Laboratory Genetics, Medical University of Lodz, 251 Pomorska St., $92-213$ Lodz, Poland.

E-mail address: franiak.ida@gmail.com (I. Franiak-Pietryga).
} 


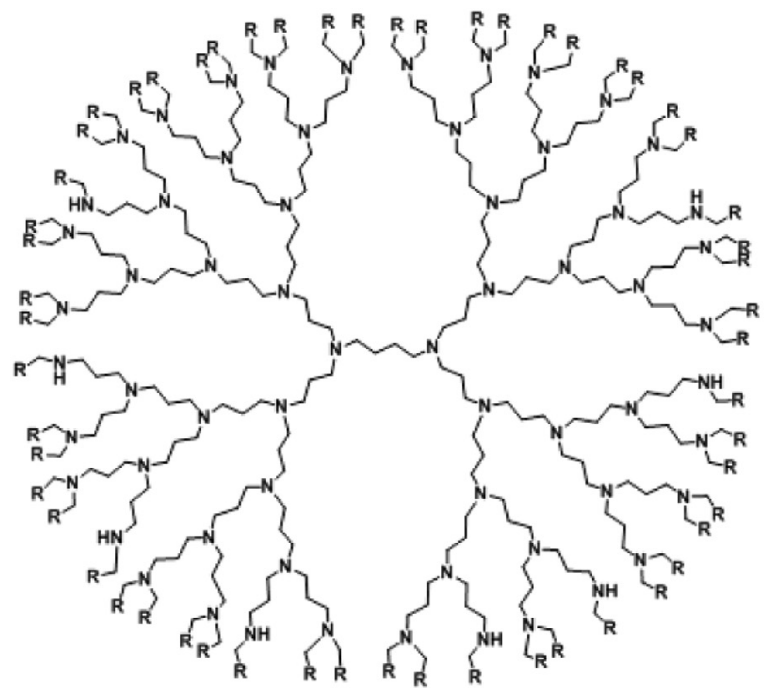

PPI-G4-DS-M3

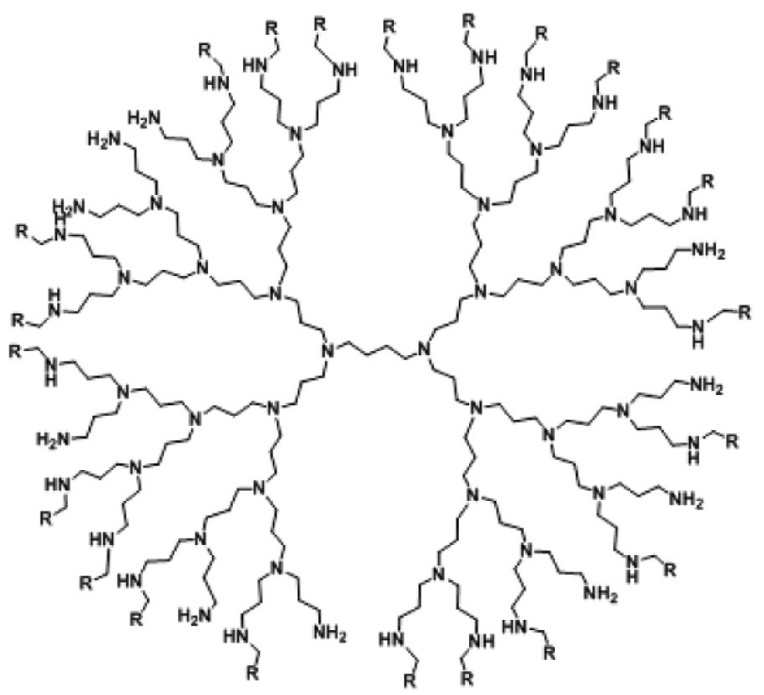

PPI-G4-OS-M3

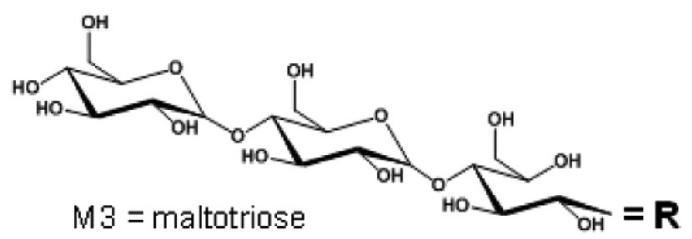

Fig. 1. Simplified structure of PPI-G4-DS-M3 and PPI-G4-OS-M3 dendrimers.

et al., 2017a; Franiak-Pietryga et al., 2013; Franiak-Pietryga et al., 2017b). Dendrimers are currently one of the most popular nanoparticles and they have been well described in many previous publications, e.g. (de Brabander-Van Den Berg and Meijer, 1993; Jain et al., 2010; Tomalia and Fréchet, 2002; Ziemba et al., 2012a). In short, they are well-defined, monodisperse, three-dimensional structures with a central core and functional terminal groups (Tomalia et al., 1985). Because of their unique structure and properties, dendrimers have attracted great interest in biomedical applications e.g. as polymeric agents in cancer diagnosis and therapy (Baker, 2009; Kesharwani et al., 2014; Menjoge et al., 2010; Svenson and Tomalia, 2012).

In previous works it was proved that PPI-G4-OS/DS-M3 dendrimers reveal low cyto- (Ziemba et al., 2014), geno- (Ziemba et al., 2012b), hemo-(Ziemba et al., 2012c) and in vivo ${ }^{21}$ toxicity (Ziemba et al., 2011). However, it was also indicated that PPI glycodendrimers induce apoptosis in cancer cells, including CLL, and inhibit their proliferation without significant influence on normal lymphocytes viability (FraniakPietryga et al., 2013; Ziemba et al., 2014). Moreover, results in one of our recent study show that PPI-G4-OS-M3 dendrimer significantly influences pro- and antiapoptotic gene and protein expression in CLL cells (Franiak-Pietryga et al., 2017b).

In this paper, we focused on the influence of PPI-G4-OS/DS-M3 dendrimers on nuclear factor- $\mathrm{\kappa B}(\mathrm{NF \kappa B})$ signaling pathway genes expression as it is one of the potential targeting patterns for CLL therapy. NF- $\kappa \mathrm{B}$ transcription factors family consists of p65 (RelA), RelB, c-Rel,

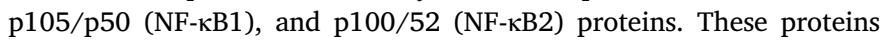
play a meaningful role in inflammation and immunity, as well as in cells proliferation, differentiation, and survival (Oeckinghaus and Ghosh, 2009). The major role of NF- $\mathrm{kB}$ in the pathogenesis of B-cell neoplasms is well established and a broad array of, mostly extracellular, stimuli has been reported to directly activate NF- $\mathrm{KB}$ in CLL cells (Liu et al., 2011). The stimuli include: induction of GSK-3 $\beta$ (Ougolkov et al., 2007), activation of the Tumor Necrosis Factor receptor (TNFR) family members, leukemia/lymphoma-1 (TCL1) oncogene deregulation of the $\mathrm{T}$ cell (Liu et al., 2011), activation of Notch signaling (Rosati et al.,
2009), activation of the cell surface receptor CD40 (Polager and Ginsberg, 2008) or modulation of epigenetic regulators (Chen et al., 2009). Recent data pointed out that NF-KB is activated by the binding of unphosphorylated signal transducer and activator of transcription (STAT3) to the NF-kB dimers $\mathrm{p} 65 / \mathrm{p} 50$ in competition with the inhibitor

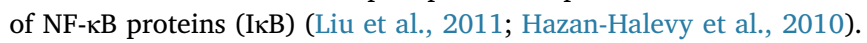

The present work is part of a series of publications describing the effect of PPI glycodendrimers on signaling pathway gene expression in CLL cells. The results of microarray analysis for BCR, TRAIL and WNT have already been published (Franiak-Pietryga et al., 2017a; FraniakPietryga et al., 2017c; Franiak-Pietryga et al., 2016) and they indicate that glycodendrimers significantly modulate expression of the examined genes thereby reducing the CLL cells survival. Findings of these preliminary results might be of an importance considering the usage of PPI dendrimers as active compounds in the future.

\section{Material and methods}

\subsection{Fludarabine}

Commercially available Fludarabine (FA, Genzyme) was used in the study. Chosen concentration of $1.6 \mu \mathrm{M}$ is the $\mathrm{IC}_{50}$ of $\mathrm{FA}$ in 24 -h culture and was calculated on the basis of previous studies (Ziółkowska et al., 2012; Zaborowska et al., 2009). It is close to the concentration of the drug given to patients during the standard treatment protocol (Korycka and Robak, 2003).

\subsection{Dendrimers}

Two sets of 4th generation poly(propylene imine) dendrimers (PPIG4) with peripheral amino groups modified with maltotriose units (M3) in approximately 90\% (labeled as the dense shell (DS); PPI-G4-DS-M3) and $35 \%$ (labeled as the open shell (OS); PPI-G4-OS-M3) were used. The concentration of $8 \mathrm{mg} / \mathrm{mL}$ was chosen based on the results of our previous study (Franiak-Pietryga et al., 2015) since it is the IC $_{50}$ value for 
Table 1

Molar mass $\left(\mathrm{MM}^{\mathrm{a}}\right)$ for synthesized dendrimers, with the number and the percentage of surface maltotriose groups.

\begin{tabular}{lll}
\hline Dendrimer & MM $[\mathrm{g} / \mathrm{mol}]$ & Number (percentage) of surface M3 groups \\
\hline PPI-G4-OS-M3 & 14,260 & $22(35 \%)$ \\
PPI-G4-DS-M3 & 31,000 & $56(87 \%)$
\end{tabular}

${ }^{\mathrm{a}} \mathrm{MM}$ of glycodendrimer determined by ${ }^{1} \mathrm{H}$ NMR approach [(500 $\mathrm{MHz}, \mathrm{D}_{2} \mathrm{O}$, $\delta$ ) for the molar ratio between x-times of 2 protons for anomeric $\mathrm{H}$ of maltotriose and 124 protons for internal $\mathrm{CH}_{2}$ groups, used as reference, of dendritic poly(propylene imine) scaffold: $4.9-5.3$ (s, x-time $2 \mathrm{H}$, anomeric $\mathrm{H}$ of maltotriose) and 1.4-2.3 ppm (124H for internal $\mathrm{CH}_{2}$-groups).] approach described in (Mkandawire et al., 2009).

PPI-G4-OS-M3 in 48-h culture. Synthesis of the glycodendrimers (GD) was carried out as described elsewhere (Appelhans et al., 2010; Mkandawire et al., 2009). The dendrimer structures are given in Fig. 1 and the general characteristics is presented in Table 1.

\subsection{Cell culture and treatment}

The MEC-1 homogenous cell line with del(17p)(11q) mutation (DSMZ no. ACC 497) was used. Cells were treated as described in previous papers (Franiak-Pietryga et al., 2017b; Franiak-Pietryga et al., 2017c; Franiak-Pietryga et al., 2016). For the treatment cells were incubated with either FA $(1.6 \mu \mathrm{M})$ or $\mathrm{GD}(8 \mathrm{mg} / \mathrm{mL})$, up to $4 \mathrm{~h}$. Cultures without GD or FA were used as reference (Ref).

\subsection{Microarray gene expression analysis}

Microarray gene expression assay (Agilent SurePrint Technologies, USA) was performed as it was described previously (Franiak-Pietryga et al., 2017b). Samples were hybridized to an $8 \times 60 \mathrm{~K}$ whole human genome microarray and the arrays were scanned on an Agilent DNA Microarray Scanner. Two replicate hybridizations and dye-swap were carried out for each experiment. All microarray data were deposited at the Gene Expression Omnibus (GEO) with the accession number GSE68094.

Microarray data analysis was performed as it was described previously (Franiak-Pietryga et al., 2017b).

\section{Results}

\subsection{Microarray gene expression profiling}

We investigated the influence of PPI-G4-OS/DS-M3 dendrimers on NFKB pathway genes expression in MEC-1 cells as on the one of the major factors in the pathogenesis of B-cell neoplasms. We compared the findings with results obtained for FA, a drug commonly used in CLL treatment (Fig. 2).

The gene descriptions and the details concerning their expression with the $p$-value indicating differential expression between the sample of interest (FA, PPI-G4-OS-M3, PPI-G4-DS-M3) and the Ref are collected in Table 2. Comparison of gene expression between GD and FA treated cells is presented in Table 3.

A comparison between PPI-G4-OS-M3 and PPI-G4-DS-M3 dendrimers mode of action on the cell culture revealed that both groups of dendrimers induced the same sets of genes (REL, RELB and NFKBIB) (Table 3). Analogous comparison between FA and dendrimers showed differences in the gene expression in the NF- $\mathrm{KB}$ signaling pathway. We have noted that FA in the 4-h culture caused overexpression of REL, RELB and NFKBIB (Table 2). The heatmap reflects significant genes expression differences in NF- $\mathrm{KB}$ signaling pathway under the influence of both FA and GD in comparison with reference (FA/Ref and Dendrimer/Ref), shown in Fig. 3.

\section{Discussion}

For decades, treatment of CLL has been established on chemotherapy. Despite the improvement of survival by the use of chemoimmunotherapy, most patients carrying CLL burden will relapse eventually. Currently the treatment of patients with CLL is undergoing fundamental changes (Burger et al., 2017). One promising approach to achieve more durable responses might be the development of glycodendrimers coated with sugar layer which presents unique and functional characteristics (Kakkar and Balakrishnan, 2015; Eichhorst et al., 2016).

Following many novel approaches in CLL examination and the molecular methodology our study is based on the gene expression profiling (GEP) by microarrays to identify the specific target in CLL treatment to apply maltotriose-modified PPI glycodendrimers. In the current study we found a direct link between different expression profile and the examined compounds. By using the network analysis a unique gene expression signature composed of three genes: NFKBIA, $B C L 3$ and CHUK differentiated between cultures treated with PPI dendrimers and FA.

Conserved helix-loop-helix ubiquitous kinase (CHUK) encoded by the CHUK gene is also known as the inhibitor of nuclear factor kappa-B kinase subunit alpha (IKK- $\alpha$ or IKK1) and it is a part of the IкB kinase (IKK) complex that plays an important role in regulating the NF- $\mathrm{KB}$ transcription factor.

NF- $\mathrm{KB}$ mediates cross-talk between BCR and TNFR signaling (Rickert et al., 2011). As discussed earlier, activation of the proximal BCR signaling complex ultimately results in activation of IKK1/IKK2, phosphorylation and proteosomal degradation of IкB $\alpha$ and induction of

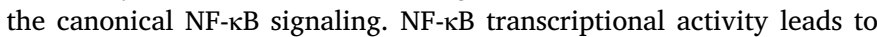
upregulation of a number of chemokine molecules (CCL17, CCL22, CXCR5); cell cycle regulators (Cyclin D) and the anti-apoptotic proteins mentioned above. In a positive feedback mechanism, canonical NF- $\kappa \mathrm{B}$ signaling enhances transcription of the non-canonical NF- $\mathrm{BB}$ pathway components (such as p100), as well as c-Rel and BAFF-R which are critical for BAFF-R signaling. Hence the NF- $\mathrm{KB}$ pathway represents an attractive target in B-cell malignancies. Moreover, CD40L- or BAFFmediated NF- $\mathrm{KB}$ activation has strong clinical implications in that it may render malignant $\mathrm{B}$ cells less dependent on BCR signaling targeting agents ultimately leading to resistance to BCR-targeting agents (Rickert et al., 2011). However, our data shows that FA more upregulate the expression of CHUK gene rather than both glycodendrimers, the differences are not very significant as well as it is still very short time of observation $(4 \mathrm{~h})$ and we expect different results after extended incubation time.

The gene B-cell CLL/lymphoma 3 (BCL3) belongs to I $\mathrm{KB}$ family and was initially identified as a candidate for a proto-oncogene located adjacent to the breakpoint of $t(14 ; 19)(\mathrm{q} 32 ; \mathrm{q} 13)$ in some patients with CLL (Nishikori et al., 2003; McKeithan et al., 1994; Ohno et al., 1990; Chang and Vancurova, 2014; Mckeithan et al., 1997; Mitchell et al., 2001). Unlike other IкBs, BCL3 is a predominantly nuclear protein, containing a transactivation domain, and can be recruited to NFkB-responsive promoters. This results in a transcriptional activation or repression, depending on the composition of NFKB complexes (Ge et al., 2003). Overexpression of BCL3 is also directed to an increased survival, cell proliferation and malignant potential.

The hallmark of NFKBI protein family is the presence of multiple ankyrin repeats and their ability to associate with the NF- $\mathrm{KB}$ protein. The NFKBIA (IкB $\alpha$ ) is characterized by 3 regions: an N-terminal region with phosphorylation sites, a C-terminal PEST region regulating basal degradation and an ankyrin repeat domain (Jacobs and Harrison, 1998; Zhao et al., 2014). The NFKBIA gene is found on chromosome 14 and contains 6 exons. Polymorphisms and haplotypes of NFKBIA and mutations have been found in many diseases such as melanoma, Hodgkin's lymphoma, colorectal cancer, hepatocellular carcinoma, multiple myeloma or breast cancer (He et al., 2009; Liu et al., 2010; Bu et al., 


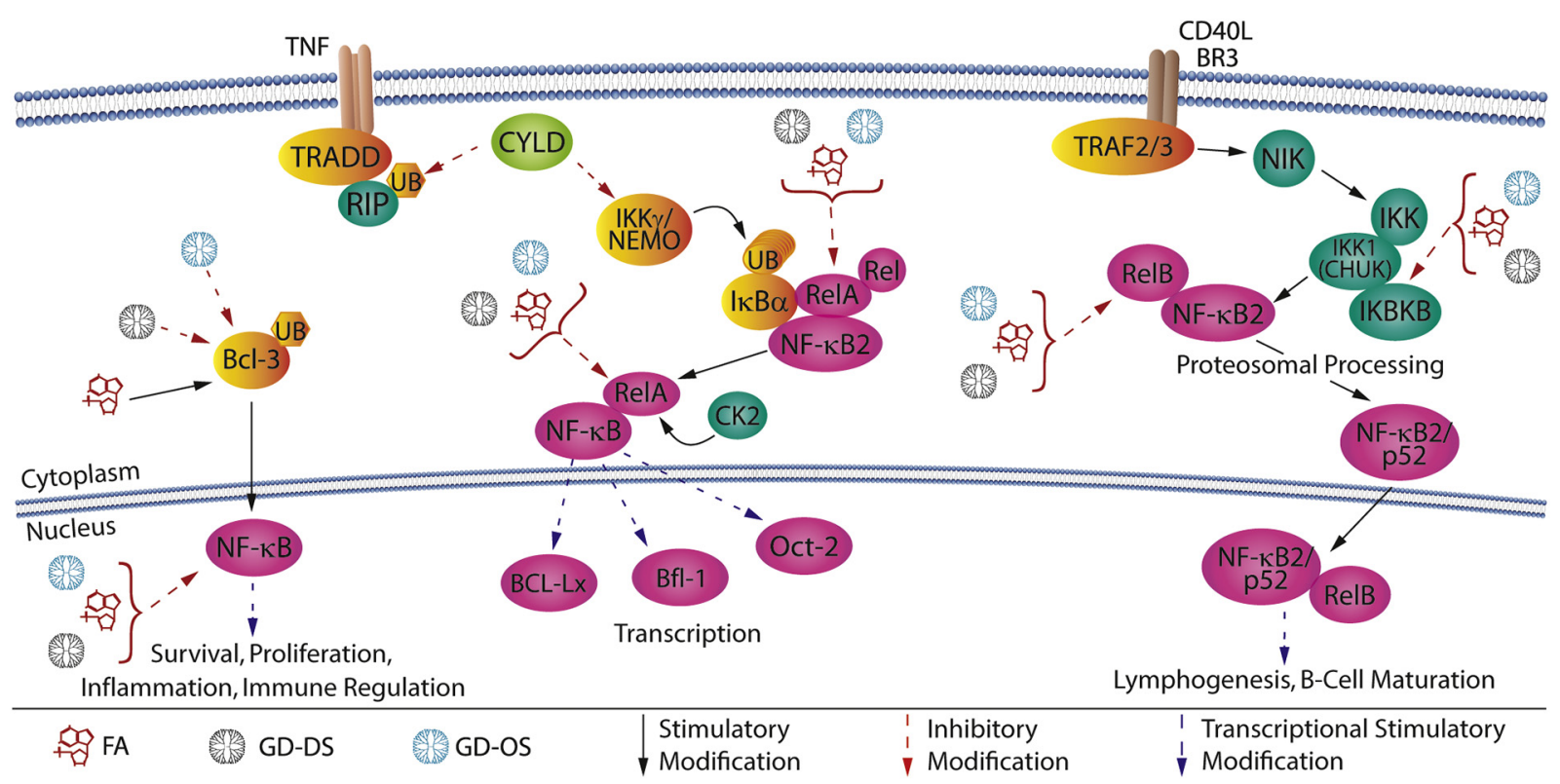

Fig. 2. A comparison between glycodendrimers (GD) and fludarabine (FA) mode of action on NF-kB cell signaling pathway in chronic lymphocytic leukemia cells.

Table 2

NF- $\mathrm{BB}$ gene expression in MEC-1 cells under the influence of PPI-G4-OS-M3, PPI-G4-DS-M3 and FA in 4-h-cultures; comparison with Ref.

\begin{tabular}{|c|c|c|c|c|c|}
\hline & Probe set & Gene symbol & Gene full name & $\operatorname{LogFC}$ & Statistical analysis $P$ value \\
\hline PPI-G4-OS-M3/ & P330895 & NFKBIB & Nuclear factor of kappa light polypeptide gene enhancer in B-cell inhibitor, beta & 1.2943 & 0.0002 \\
\hline \multirow[t]{5}{*}{ Ref } & P56938 & $R E L$ & V-rel avian reticuloendotheliosis viral oncogene homolog & 0.7639 & 0.0005 \\
\hline & P106002 & NFKBIA & Nuclear factor of kappa light polypeptide gene enhancer in B-cell inhibitor, alfa (IкB $\alpha$ ) & -0.6581 & 0.001 \\
\hline & P55706 & $R E L B$ & V-rel avian reticuloendotheliosis viral oncogene homolog B & 0.6076 & 0.002 \\
\hline & P30655 & NFKBIE & Nuclear factor of kappa light polypeptide gene enhancer in B-cell inhibitor, epsilon & -0.8388 & 0.01 \\
\hline & P3209433 & $R E L A$ & V-rel avian reticuloendotheliosis viral oncogene homolog A & 0.2533 & 0.05 \\
\hline \multirow[t]{3}{*}{ PPI-G4-DS-M3/Ref } & P56938 & $R E L$ & V-rel avian reticuloendotheliosis viral oncogene homolog & 0.9975 & 0.0001 \\
\hline & P330895 & NFKBIB & Nuclear factor of kappa light polypeptide gene enhancer in B-cell inhibitor, beta & 1.2535 & 0.0002 \\
\hline & P55706 & $R E L B$ & V-rel avian reticuloendotheliosis viral oncogene homolog B & 0.6551 & 0.001 \\
\hline \multirow[t]{3}{*}{$\mathrm{FA} /$ Ref } & P56938 & $R E L$ & V-rel avian reticuloendotheliosis viral oncogene homolog & 0.6598 & 0.001 \\
\hline & P55706 & $R E L B$ & V-rel avian reticuloendotheliosis viral oncogene homolog B & 0.6953 & 0.001 \\
\hline & P330895 & NFKBIB & Nuclear factor of kappa light polypeptide gene enhancer in B-cells inhibitor, beta & 0.8904 & 0.001 \\
\hline
\end{tabular}

Table 3

Apoptotic gene expression in MEC-1 cells under the influence of glycodendrimers in 4-h-cultures; comparison with FA.

\begin{tabular}{|c|c|c|c|c|c|}
\hline & Probe set & Gene symbol & Gene full name & $\operatorname{LogFC}$ & $\begin{array}{l}\text { Statistical analysis } \\
\mathrm{P} \text { value }\end{array}$ \\
\hline \multirow[t]{3}{*}{ PPI-G4-OS-M3/FA } & P106002 & NFKBIA & Nuclear factor of kappa light polypeptide gene enhancer in B-cell inhibitor, alfa (IкB $\alpha$ ) & -0.4580 & 0.04 \\
\hline & P4662 & $B C L 3$ & B-cell CLL/lymphoma 3 & -0.6212 & 0.04 \\
\hline & P3258141 & CHUK & Conserved helix-loop-helix ubiquitous kinase & -0.3954 & 0.05 \\
\hline \multirow[t]{4}{*}{ PPI-G4-DS-M3/FA } & P4662 & $B C L 3$ & B-cell CLL/lymphoma 3 & -0.6488 & 0.04 \\
\hline & P56938 & $R E L$ & V-rel avian reticuloendotheliosis viral oncogene homolog & 0.3376 & 0.06 \\
\hline & P3258141 & CHUK & Conserved helix-loop-helix ubiquitous kinase (IKK1) & -0.3363 & 0.08 \\
\hline & P106002 & NFKBIA & Nuclear factor of kappa light polypeptide gene enhancer in B-cell inhibitor, alfa & 0.3208 & 0.09 \\
\hline
\end{tabular}

2007; Spink et al., 2007). Alterations render NFKBIA proteins important from a clinical point of view mainly because they are incapable of interacting with NF- $\mathrm{kB}$, NFKBIA lose their activity, and thus resulting in the loss of protection of tumor cells from apoptosis. RELB silencing may be involved in the development of resistant subtypes of CLL in males (Marteau et al., 2010). Our results show that glycodendrimers increase the expression of this gene.

Lymphoid microenvironment promotes survival, proliferation and finally progression of CLL cells through chronic activation of NF-KB while suppressing the immune response (Mittal et al., 2014). In the current study, we show that the addition of PPI-G4-OS-M3 and PPI-G4DS-M3 dendrimers to B-CLL cells significantly induces apoptosis phenomenon within this lymphocytes by significant reduction of their survival ratio.

Since 2012 our team has investigated the PPI-G4-M3 dendrimers as potential drug in CLL therapy (Franiak-Pietryga et al., 2013) evidently proving that PPI glycodendrimers strongly influence the survival of cancer cells by inducing apoptosis and inhibiting their proliferation but do not exert significantly harmful effect on normal lymphocytes (Franiak-Pietryga et al., 2013; Ziemba et al., 2014). Moreover, PPI-G4 glycodendrimers mainly modulate pro- and antiapoptotic gene and protein expression in CLL cells (Franiak-Pietryga et al., 2017b).

\section{Conclusions}

According to our previous results, we can indicate many genetic 


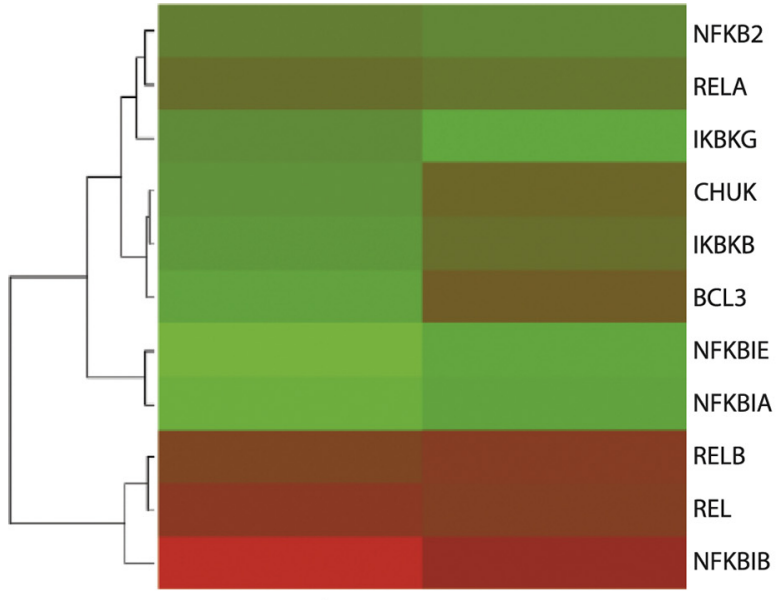

PPI-G4-DS-M3
FA

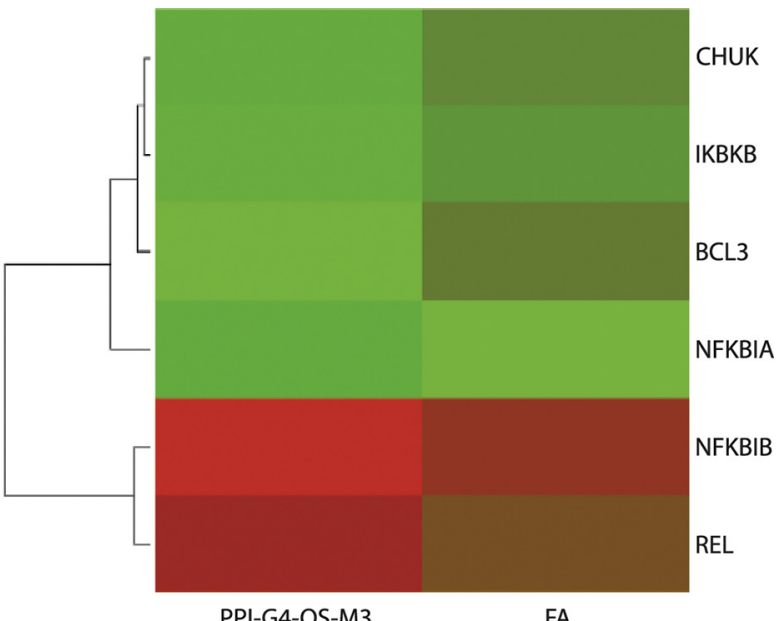

PPI-G4-OS-M3

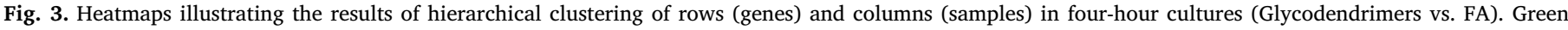

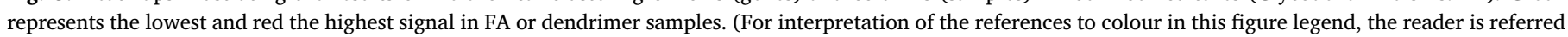
to the web version of this article.)

targets in CLL that glycodendrimers (GD) may work with. This is totally different from the drug currently available in the market. The effect of GD is based on triggering different genes simultaneously, starting a domino effect with the rest of the pathways. The effect of apoptosis begins in the inner part of the cell as soon as the dendrimer is endocytozed. The apoptosis comes directly from the mitochondria and secondly triggers external pathway. Since the mechanism starts in the middle of cell, it is much easier to turn on different genes simultaneously. This is the 'trojan horse' effect - the most efficient sort of treatment. We already know a lot about GD but there are still uncharted waters remaining where we can find tremendous potential of GD in biomedical applications. Thus, further research is fully justified for validating the potential of glycodendrimers as polymeric drug under in vivo conditions.

\section{Conflicts of interest}

There are no conflicts to declare.

\section{Acknowledgements}

Authors thank Mr. Zinke for carrying out synthesis and purification of glycodendrimers (IPF Dresden) and Mr. Komber for NMR measurements (IPF Dresden). The study was partially supported by Grant No. DEC-2011/01/B/NZ5/01371 from the National Science Centre, Poland. The results were partially presented as a poster at the 57th ASH Meeting, December 5-8, 2015, Orlando, USA (abstract 86362). The intellectual property is protected by two patents US 9,877,985 and US $10,022,395$.

\section{References}

Appelhans, D., Oertel, U., Mazzeo, R., Komber, H., Hoffmann, J., Weidner, S., Brutschy, B., Voit, B., Ottaviani, M.F., 2010. Proc. R. Soc. A 466, 1489-1513.

Baker, J.R., 2009. Hematol. Am. Soc. Hematol. Educ. Program 708-719.

Bu, H., Rosdahl, I., Sun, X.-F., Zhang, H., 2007. J. Cancer Res. Clin. Oncol. 133, 859-866. Burger, J.A., Li, K.W., Keating, M.J., Sivina, M., Amer, A.M., Garg, N., Ferrajoli, A.,

Huang, X., Kantarjian, H., Wierda, W.G., O'Brien, S., Hellerstein, M.K., Turner, S.M., Emson, C.L., Chen, S.-S., Yan, X.-J., Wodarz, D., Chiorazzi, N., 2017. JCI Insight 2, $1-11$.

Byrd, J.C., Furman, R.R., Coutre, S.E., Burger, J.A., Blum, K.A., Coleman, M., Wierda, W.G., Jones, J.A., Zhao, W., Heerema, N.A., Johnson, A.J., Shaw, Y., Bilotti, E., Zhou, C., James, D.F., O'Brien, S., 2015. Blood 125, 2497-2506.

Chang, T.P., Vancurova, I., 2014. Biochim. Biophys. Acta - Mol. Cell Res. 1843, 2620-2630.

Chen, S.-S., Raval, A., Johnson, A.J., Hertlein, E., Liu, T.-H., Jin, V.X., Sherman, M.H., Liu, S.-J., Dawson, D.W., Williams, K.E., Lanasa, M., Liyanarachchi, S., Lin, T.S., Marcucci,
G., Pekarsky, Y., Davuluri, R., Croce, C.M., Guttridge, D.C., Teitell, M.A., Byrd, J.C. Plass, C., 2009. Proc. Natl. Acad. Sci. U. S. A. 106, 13433-13438.

de Brabander-Van Den Berg, E.M.M., Meijer, E.W., 1993. Angew. Chem. Int. Ed. Eng. 32, 1308-1311.

E. Doménech, G. Gómez-López, D. Gzlez-Peña, M. López, B. Herreros, J. Menezes, N. Gómez-Lozano, A. Carro, O. Graña, D. G. Pisano, O. Domínguez, J. A. García-Marco, M. A. Piris and M. Sánchez-Beato, PLoS One, 2012, DOI:https://doi.org/10.1371/ journal.pone.0038158.

Eichhorst, B., Fink, A.-M., Bahlo, J., Busch, R., Kovacs, G., Maurer, C., Lange, E., Köppler, H., Kiehl, M., Sökler, M., Schlag, R., Vehling-Kaiser, U., Köchling, G., Plöger, C., Gregor, M., Plesner, T., Trneny, M., Fischer, K., Döhner, H., Kneba, M., Wendtner, C. M., Klapper, W., Kreuzer, K.-A., Stilgenbauer, S., Böttcher, S., Hallek, M., 2016. International group of investigators and German CLL Study Group (GCLLSG). Lancet Oncol. 17, 928-942.

Franiak-Pietryga, I., Ziółkowska, E., Ziemba, B., Appelhans, D., Voit, B., Szewczyk, M., Góra-Tybor, J., Robak, T., Klajnert, B., Bryszewska, M., 2013. Mol. Pharm. 10, 2490-2501.

Franiak-Pietryga, I., Ziolkowska, E., Ziemba, B., Appelhans, D., Voit, B., Gora-Tybor, J., Robak, T., Klajnert, B., Bryszewska, M., 2015. Blood 120, 4601.

Franiak-Pietryga, I., Maciejewski, H., Ostrowska, K., Appelhans, D., Voit, B., Misiewicz, M., Kowalczyk, P., Bryszewska, M., Borowiec, M., 2016. Int. J. Biol. Macromol. 88, $156-161$.

Franiak-Pietryga, I., Maciejewski, H., Ziemba, B., Appelhans, D., Voit, B., Robak, T., Jander, M., Treliński, J., Bryszewska, M., Borowiec, M., 2017a. Macromol. Biosci., 1700130.

Franiak-Pietryga, I., Ziółkowska, E., Ziemba, B., Appelhans, D., Maciejewski, H., Voit, B., Kaczmarek, A., Robak, T., Klajnert-Maculewicz, B., Cebula-Obrzut, B., Smolewski, P., Borowiec, M., Bryszewska, M., 2017b. Anti Cancer Agents Med. Chem. 17, 102-114.

Franiak-Pietryga, I., Ostrowska, K., Maciejewski, H., Appelhans, D., Misiewicz, M., Ziemba, B., Bednarek, M., Bryszewska, M., Borowiec, M., 2017c. Macromol. Biosci. $17,1600169$.

Ge, B., Li, O., Wilder, P., Rizzino, A., McKeithan, T.W., 2003. J. Immunol. 171, 4210-4218.

Hazan-Halevy, I., Harris, D., Liu, Z., Liu, J., Li, P., Chen, X., Shanker, S., Ferrajoli, A., Keating, M.J., Estrov, Z., 2010. Blood 115, 2852-2863.

He, Y., Zhang, H., Yin, J., Xie, J., Tan, X., Liu, S., Zhang, Q., Li, C., Zhao, J., Wang, H., Cao, G., 2009. Carcinogenesis 30, 1916-1922.

Jacobs, M.D., Harrison, S.C., 1998. Cell 95, 749-758.

Jain, K., Kesharwani, P., Gupta, U., Jain, N.K., 2010. Int. J. Pharm. 394, 122-142.

Kakkar, A.K., Balakrishnan, S., 2015. J. Oncol. Pharm. Pract. 21, 358-363.

Kesharwani, P., Jain, K., Jain, N.K., 2014. Prog. Polym. Sci. 39, 268-307.

Korycka, A., Robak, T., 2003. Leuk. Lymphoma 44, 1549-1555.

Liu, X., Yu, H., Yang, W., Zhou, X., Lu, H., Shi, D., 2010. Cancer Genet. Cytogenet. 197, $152-157$.

Liu, Z., Hazan-Halevy, I., Harris, D.M., Li, P., Ferrajoli, A., Faderl, S., Keating, M.J., Estrov, Z., 2011. Mol. Cancer Res. 9, 507-515.

Marteau, J.-B., Rigaud, O., Brugat, T., Gault, N., Vallat, L., Kruhoffer, M., Orntoft, T.F., Nguyen-Khac, F., Chevillard, S., Merle-Beral, H., Delic, J., 2010. J. Mol. Biol. 397, $1-12$.

McKeithan, T.W., Ohno, H., Dickstein, J., Hume, E., 1994. Genomics 24, 120-126.

Mckeithan, T.W., Takimoto, G.S., Ohno, H., Bjorling, V.S., Morgan, R., Hecht, B.K., Dube, I., Sandberg, A.A., Rowley, J.D., 1997. Genes Chromosom. Cancer 72, 64-72.

Menjoge, A.R., Kannan, R.M., Tomalia, D.A., 2010. Drug Discov. Today 15, 171-185.

Mitchell, T.C., Hildeman, D., Kedl, R.M., Teague, T.K., Schaefer, B.C., White, J., Zhu, Y., Kappler, J., Marrack, P., 2001. Nat. Immunol. 2, 397-402.

Mittal, A.K., Chaturvedi, N.K., Rai, K.J., Gilling-Cutucache, C.E., Nordgren, T.M., Moragues, M., Lu, R., Opavsky, R., Bociek, G.R., Weisenburger, D.D., Iqbal, J., Joshi, 
S.S., 2014. Mol. Med. 20, 290-301.

Mkandawire, M., Pohl, A., Gubarevich, T., Lapina, V., Appelhans, D., Rödel, G., Pompe, W., Schreiber, J., Opitz, J., 2009. J. Biophotonics 2, 596-606.

Nishikori, M., Maesako, Y., Ueda, C., Kurata, M., Uchiyama, T., Ohno, H., 2003. Blood 101, 2789-2796.

Oeckinghaus, A., Ghosh, S., 2009. Cold Spring Harb. Perspect. Biol. 1.

Ohno, H., Takimoto, G., McKeithan, T.W., 1990. Cell 60, 991-997.

Ougolkov, A.V., Bone, N.D., Fernandez-Zapico, M.E., Kay, N.E., Billadeau, D.D., 2007.

Blood 110, 735-742.

Polager, S., Ginsberg, D., 2008. Trends Cell Biol. 18, 528-535.

Ramanathan, S., Jin, F., Sharma, S., Kearney, B.P., 2016. Clin. Pharmacokinet. 55, 33-45. Rickert, R.C., Jellusova, J., Miletic, A.V., 2011. Immunol. Rev. 244, 115-133.

Rosati, E., Sabatini, R., Rampino, G., Tabilio, A., Di Ianni, M., Fettucciari, K., Bartoli, A., Coaccioli, S., Screpanti, I., Marconi, P., 2009. Blood 113, 856-865.

Smolej, L., 2016. Curr. Cancer Drug Targets 16, 710-720.

Spink, C.F., Gray, L.C., Davies, F.E., Morgan, G.J., Bidwell, J.L., 2007. Cancer Lett. 246, 92-99.

Svenson, S., Tomalia, D.A., 2012. Adv. Drug Deliv. Rev. 64, 102-115.

Tam, C.S., O'Brien, S., Wierda, W., Kantarjian, H., Wen, S., Do, K.-A., Thomas, D.A.,

Cortes, J., Lerner, S., Keating, M.J., 2008. Blood 112, 975-980.
Tomalia, D.A., Fréchet, J.M.J., 2002. J. Polym. Sci. Part A Polym. Chem. 40, 2719-2728. Tomalia, D.A., Baker, H., Dewald, J., Hall, M., Kallos, G., Martin, S., Roeck, J., Ryder, J., Smith, P., 1985. Polym. J. 17, 117-132.

Zaborowska, A., Cebula-Obrzut, B., Franiak-Pietryga, I., Błoński, J.Z., Smolewski, P., Robak, T., Korycka-Wołowiec, A., 2009. Acta Haematol. Pol. 40, 887-898.

Zhao, Z., Zhong, X., Wu, T., Yang, T., Chen, G., Xie, X., Wei, Y., Ye, M., Zhou, Y., Du, Z., 2014. Int. J. Mol. Med. 34, 1233-1240.

Ziemba, B., Janaszewska, A., Ciepluch, K., Krotewicz, M., Fogel, W.A., Appelhans, D., Voit, B., Bryszewska, M., Klajnert, B., 2011. J. Biomed. Mater. Res. - Part A 99 A, 261-268.

Ziemba, B., Matuszko, G., Bryszewska, M., Klajnert, B., 2012a. Cell. Mol. Biol. Lett. 17, 21-35.

Ziemba, B., Matuszko, G., Appelhans, D., Voit, B., Bryszewska, M., Klajnert, B., 2012b. Biopolymers 97, 642-648.

Ziemba, B., Halets, I., Shcharbin, D., Appelhans, D., Voit, B., Pieszynski, I., Bryszewska, M., Klajnert, B., 2012c. J. Biomed. Mater. Res. A 100, 2870-2880.

Ziemba, B., Franiak-Pietryga, I., Pion, M., Appelhans, D., Muñoz-Fernández, M.Á., Voit, B., Bryszewska, M., Klajnert-Maculewicz, B., 2014. Int. J. Pharm. 461, 391-402.

Ziółkowska, E., Franiak-Pietryga, I., Cebula-Obrzut, B., Błońsk, J., Robak, T., Smolewski, P., Korycka-Wołowiec, A., 2012. Postepy Hig. Med. Dosw. 66, 730-738. 